\title{
PROFITABILITY AND WORKING CAPITAL MANAGEMENT: EVIDENCE FROM THE WARSAW STOCK EXCHANGE
}

\author{
Jacek JAWORSKI (D) ${ }^{\star}$, Leszek CZERWONKA (D2 \\ ${ }^{1}$ Department of Finance, WSB University in Gdańsk, Gdańsk, Poland \\ ${ }^{2}$ Faculty of Economics, University of Gdańsk, Gdańsk, Poland
}

Received 27 March 2020; accepted 18 March 2021

\begin{abstract}
The aim of this paper is to identify the relationships between measures of working capital management (cash conversion cycle /CCC/, working capital value / $\mathrm{WC} /$ and the financial liquidity $/ \mathrm{CR} /$ ) and profitability of companies listed on the Warsaw Stock Exchange. The research material consisted of data of 326 companies from 1998-2016. The analysis revealed significant non-linear relationship between WC, CR and profitability. When WC and CR values grow, profitability increases, but at a slower pace. However, there is a linear negative relationship between CCC and profitability. The results are influenced by the industry and the GDP growth. This indicates that profit-driven entrepreneurs try to delay payments to suppliers. They pay off bank loans from the funds thus generated. This study contributes to the verification of theories linking profitability with working capital management with emphasis on the influence of the industry. The results have practical implications: companies with growing profitability should not lose sight of the shortening CCC when paying off short-term loans; in some industries decreasing profitability while CR values grow may mean problems with the efficient use of current assets.
\end{abstract}

Keywords: profitability, liquidity, working capital management, cash conversion cycle, current ratio, Warsaw Stock Exchange.

JEL Clssification: G30, M20, L25.

\section{Introduction}

Research on corporate finance can be divided into two main areas. The first one is related to the long-term financial policy of enterprises (investments, capital structure, dividend policy and company valuation). It is an area of research undertaken for many years. The second research area, related to the short-term financial policy of enterprises, has been developing for a much shorter time. This subject began to interest researchers at the beginning of the 1980s. Therefore, the scientific achievements and knowledge in this area are not so impressive (Chang, 2018; Singh et al., 2017).

${ }^{\star}$ Corresponding author. E-mail: jjaworski@wsb.gda.pl

Copyright (C) 2022 The Author(s). Published by Vilnius Gediminas Technical University

This is an Open Access article distributed under the terms of the Creative Commons Attribution License (http://creativecommons. org/licenses/by/4.0/), which permits unrestricted use, distribution, and reproduction in any medium, provided the original author and source are credited. 
A company's short-term financial policy is primarily based on the working capital management (WCM) which consists of decisions on determining the amount and turnover of current assets in connection with the payment of short-term liabilities. These decisions should result in a surplus of revenue over the costs (profitability). Therefore, it can be assumed that there is a relationship between the profitability and the basic categories considered as measures for the management of working capital.

Three theoretical concepts have been developed to explain the relationship between WCM and profitability: (1) linear negative relationship (Smith, 1980), (2) linear positive relationship (Opler et al., 1999), and (3) non-linear (Gentry's curve) dependence (BañosCaballero et al., 2012). However, despite many empirical studies, it has not yet been possible to determine which of these concepts best explains the behaviour of companies. Negative relationship between WCM and profitability is the most frequently detected (e.g. Deloof, 2003; Ren et al., 2019; Le, 2019; Akgün \& Karataş, 2021), but there are many studies which investigated opposite directions (e.g. Raheman et al., 2010; Perković, 2012). Only few studies were focused on non-linear dependence (e.g. Afrifa, 2016; Boțoc \& Anton, 2017; Yilmaz \& Acar, 2019). The review of these studies leads to the conclusion that there are factors which affect the relationship between WCM and profitability. Taking into consideration countryfocused research samples in the studies, the first area of these determinants includes countrylevel factors. However, industry specific factors are also often mentioned (Capkun et al., 2009; Khan et al., 2020). Both groups of the factors that could determine the choice of one of the concepts of relationships between WCM and profitability have not been identified yet. Therefore, the described research area remains open. It is especially relevant to emerging economies from Central and Eastern Europe. One of them is Poland, having been one of the largest EU countries characterized by high economic growth for years.

In Poland, the studies on the impact of WCM on the profitability of enterprises have not gone beyond the exploratory phase. In this respect, the most prominent studies concern food industry enterprises (Bieniasz \& Gołaś, 2011; Zawadzka et al., 2011; Paszko \& Pawlak, 2014; Jaworski et al., 2018; Gołaś, 2020). The research related to the largest CEE stock exchange in Warsaw is less developed and limited to several studies (Wawryszuk-Misztal, 2007; Bolek \& Wiliński, 2012; Jaworski \& Czerwonka, 2018a, 2018b).

Filling the outlined research gap is the challenge for this study. The main goal of the paper has been to determine the relationship between the measures of WCM and profitability of companies listed on the Warsaw Stock Exchange in Poland (WSE). The research material consisted of data of 326 companies from 1998-2016. The ANOVA method and econometric panel models were used. The implementation of the goal is based on an attempt to answer the following research questions:

P1) What is the shape and direction of the relationship between WCM and profitability of enterprises listed on WSE?

P2) Which theoretical concept describes the decisions of the studied enterprises best?

P3) Does the industry, in which a particular enterprise operates, differentiate WCM dependence on profitability?

This paper contributes to the existing knowledge by: (1) complementing empirical research with comparison of results from WSE with other economies, (2) strengthening the 
verification of theories linking profitability with WCM, (3) identifying the industry as a determinant of this relationship, (4) broadening the research based on non-linear model of the relationship between WCM and profitability. This study also allows for the initiation of the research on the model describing the WCM of enterprises listed on WSE.

The paper is structured as follows: The first part presents theoretical concepts explaining the relationship between profitability and WCM. It also outlines the current state of empirical research, with a particular emphasis on the Polish economy. On the basis of literature review, the research hypotheses were formulated. In the second part, the collected research material has been presented and the applied methods of its analysis have been described. Next, the results of the research and their embedding in the existing achievements have been provided. The discussion on the results and conclusions of the research are in the last part of the paper.

\section{Theoretical background, literature review and research hypothesis}

WCM includes decisions that focus on developing adequate relations between current assets and short-term liabilities. As a result, some of these assets are financed with the capital employed (equity plus long-term liabilities) (Brealey et al., 2016). The value of these assets determines the amount of working capital (WC) which becomes the basic measure of the results of WCM (Alarussi \& Alhaderi, 2018; Diakomihalis, 2012).

The essence of current assets and short-term liabilities is a continuous turnover. Therefore, WCM means shaping the periods of conversion of current assets and repayment of liabilities (Brealey et al., 2016). The first period (the inventory turnover cycle /ITC/) is the time that elapses between the storage of inventories and their dispensation (sales). The average collection period (ACP) is the average time the company waits for the payment of receivables. During the operating cycle, which is the sum of ITC and ACP, the company pays its liabilities. The average time following the above is the accounts payable period (APP). The period resulted from comparison of the operating cycle with APP is the cash conversion cycle (CCC), during which the enterprise operates with a cash deficit. The higher WC, the longer CCC (Brealey et al., 2016; Gitman, 1974). Therefore, CCC is considered as a fundamental measure of the efficiency of WCM (Deloof, 2003; Raheman et al., 2010).

The consequence of building up WC and extending CCC increases the possibility of faster repayment of short-term liabilities. This means that WCM also applies to the creation and maintenance of an adequate level of financial liquidity. Therefore, there is a reason to believe that the level of liquidity achieved could be a good additional indicator of WCM. However, as empirical studies prove, the direction of dependence between WC and liquidity may be different, depending on the short-term financial strategy (Ebben \& Johnson, 2011; Gallinger, 1997).

Taking into consideration that maximization of long-term profit is a financial goal of enterprise the most prevalent in literature (Brealey et al., 2016), it can be assumed that there is a link between the company's profitability and the basic measures characterizing WCM. Three fundamental theoretical concepts of this relationship have been established so far. Among others, they are widely described by Li, Dong, Chen, and Yang (2014), Chang (2018) and Jaworski and Czerwonka (2018b). They are the consequence of a short-term financial strategy adopted and implemented by the company. 
The first concept is based on a flexible financial strategy. Increasing the level of WC, extending CCC combined with increasing financial liquidity allows the company to conduct sales in a more flexible manner, which has a positive impact on the dynamics of revenues and negative on costs. This concept explains the positive relationship between profitability and WCM (Deloof, 2003; Raheman et al., 2010). The second concept is related to the implementation of a restrictive financial strategy. It assumes that companies minimize the amount of WC by reducing their current assets and increasing their financing with current liabilities. This increases the business risk which, in turn, determines higher ability to generate profits. This concept explains negative relationship between profitability and WCM (Kieschnick et al., 2011; Ding et al., 2013). The third concept of the relationship between the company's profitability and WCM is an attempt to explain the simultaneous occurrence of positive and negative directions of this relationship. In a view of this concept, the relationship between profitability and working capital management is non-linear. It takes the shape of the Gentry's curve, resembling the inverted and flat U (Gentry, 1976).

Clarifying the concept of profitability - there are different measures of profitability. In the research strand to which this paper belongs, the vast majority is based on ROA, where profitability is measured as a ratio of operating profit and total assets.

The direction and strength of this dependence is determined by the amount of WC (length of CCC or liquidity level). Enterprises with a small amount of WC invest their profits primarily in increasing their payment capabilities, i.e. in WC. With an increase in profitability, the level of WCM indicators increases. After exceeding a certain level (characteristic for specific market conditions), the impact of WCM on profitability becomes difficult to identify (no obvious relationship). Further investment in working capital results in an increase in the amount of current assets financed by the capital employed. This is the reason for the increase in costs and the fall in profitability (negative dependence). This particular concept accounts for the fact that there is an optimal level of WC (length of CCC and level of liquidity) for which the company's profitability is at its maximum and does not change significantly (Baños-Caballero et al., 2012; Jaworski \& Czerwonka, 2018b).

All three abovementioned theoretical concepts have been repeatedly verified in empirical studies. Table 1 presents an overview of the most important studies with the characteristics of the research samples and the results obtained.

The review of the studies mentioned in the table leads to the conclusion that a negative linear relationship between profitability and WCM was empirically detected most often. The positive relationship was detected less frequently. The summary of research focused on the diagnosis of linear dependencies between WCM (measured by CCC) and profitability is a meta-analysis by Singh et al. (2017). In total, 46 articles containing 67 models of linear multivariable regression concerning more than a dozen countries have been subject to this analysis. The study shows that the direction of this dependence, regardless of the operating conditions of the analysed enterprises, is mostly negative.

The non-linear relationship between profitability and working capital management based on Gentry's curve was also verified empirically. First premises for identifying this relationship were pointed by Mitra and Nandi (2013) and Eljelly (2004). First authors using the example of Indian coal companies, proved that low liquidity had a positive impact on profitability. The second author detected that for high liquidity values this dependency was negative. For other values of liquidity, both studies did not indicate any statistically significant relationship. 
Table 1. The most important empirical studies on the relationship between profitability and WCM (source: own elaboration based on literature review)

\begin{tabular}{|c|c|c|}
\hline $\begin{array}{l}\text { Studies and } \\
\text { authors }\end{array}$ & Research sample & Results \\
\hline \multicolumn{3}{|c|}{ Negative relationship } \\
\hline $\begin{array}{l}\text { Deloof } \\
(2003)\end{array}$ & $\begin{array}{l}1009 \text { Belgian non-financial companies } \\
\text { between } 1992 \text { and } 1996\end{array}$ & $\begin{array}{l}\text { Strong negative relationship between } \\
\text { profitability and the length of all periods } \\
\text { of current assets and liabilities turnover } \\
\text { (including CCC) }\end{array}$ \\
\hline $\begin{array}{l}\text { Alarussi and } \\
\text { Alhaderi } \\
(2018)\end{array}$ & $\begin{array}{l}120 \text { companies listed on Bursa } \\
\text { Malaysia for the years 2012-2014 }\end{array}$ & $\begin{array}{l}\text { Strong negative relationship between } \\
\text { profitability and WC }\end{array}$ \\
\hline Le (2019) & $\begin{array}{l}497 \text { companies listed on Ho Chi Minh } \\
\text { and Hanoi stock exchange in years } \\
2007-2016\end{array}$ & $\begin{array}{l}\text { Significant, negative relationship between } \\
\text { net working capital (NWC) and firm } \\
\text { valuation, profitability and risk }\end{array}$ \\
\hline $\begin{array}{l}\text { Ren et al. } \\
\text { (2019) }\end{array}$ & $\begin{array}{l}8201 \text { listed companies from China } \\
\text { operating in years 2010-2017 }\end{array}$ & $\begin{array}{l}\text { Negative relationship between CCC and } \\
\text { firm performance }\end{array}$ \\
\hline $\begin{array}{l}\text { Kayani et al. } \\
(2020)\end{array}$ & $\begin{array}{l}\text { Australasian companies during the } \\
2008 \text { global financial crisis }\end{array}$ & $\begin{array}{l}\text { CCC exhibit negative relationship with } \\
\text { profitability }\end{array}$ \\
\hline $\begin{array}{l}\text { Akgün and } \\
\text { Karataş } \\
(2021)\end{array}$ & $\begin{array}{l}\text { 7,812 listed firms provided by Bureau } \\
\text { Van Dijk Electronic Publishing, for } \\
\text { the period } 2003 \text { to } 2012 \text { from EU-28 }\end{array}$ & $\begin{array}{l}\text { Negative relationship between gross working } \\
\text { capital and business performance }\end{array}$ \\
\hline \multicolumn{3}{|c|}{ Positive relationship } \\
\hline $\begin{array}{l}\text { Gill et al. } \\
\text { (2010) }\end{array}$ & $\begin{array}{l}88 \text { US manufacturing companies listed } \\
\text { on NYSE between } 2005 \text { and } 2007\end{array}$ & $\begin{array}{l}\text { Positive relationship between the } \\
\text { profitability and CCC and negative impact } \\
\text { of APP on profitability were identified }\end{array}$ \\
\hline $\begin{array}{l}\text { Charitou, } \\
\text { Lois, and } \\
\text { Santoso, } \\
(2012)\end{array}$ & $\begin{array}{l}56 \text { public companies from Indonesia } \\
\text { operating in } 1998-2010\end{array}$ & $\begin{array}{l}\text { Positive relationships between: 1) cash } \\
\text { conversion cycle and profitability, 2) } \\
\text { profitability and inventory turnover cycle }\end{array}$ \\
\hline $\begin{array}{l}\text { Baser et al. } \\
(2016)\end{array}$ & $\begin{array}{l}187 \text { firms listed and traded on } \\
\text { National Market of Istanbul Stock } \\
\text { Exchange in } 2014\end{array}$ & $\begin{array}{l}\text { Moderate level of positive } \\
\text { effect between liquidity and profitability }\end{array}$ \\
\hline \multicolumn{3}{|c|}{ Non-linear relationship } \\
\hline $\begin{array}{l}\text { Baños- } \\
\text { Caballero } \\
\text { et al. }(2012)\end{array}$ & $\begin{array}{l}1008 \text { small and medium enterprises } \\
\text { from Spain operating in the period } \\
2002-2007\end{array}$ & $\begin{array}{l}\text { Statistically significant square dependence } \\
\text { (inverted) of CCC on the return on sales }\end{array}$ \\
\hline Thapa (2013) & $\begin{array}{l}30 \text { US top food manufacturing } \\
\text { companies in the period } 2000-2009\end{array}$ & \multirow{2}{*}{$\begin{array}{l}\text { Statistically significant square dependence } \\
\text { (inverted) of CCC on the return on assets }\end{array}$} \\
\hline $\begin{array}{l}\text { Mun and } \\
\text { Jang (2015) }\end{array}$ & $\begin{array}{l}5812 \text { US restaurant companies doing } \\
\text { business in years } 1963-2012\end{array}$ & \\
\hline Afrifa (2016) & $\begin{array}{l}\text { 7,000 SME enterprises from the UK in } \\
\text { the period 2004-2013 }\end{array}$ & \multirow{2}{*}{$\begin{array}{l}\text { Statistically significant square relation } \\
\text { (inverted) between the lagged CCC and the } \\
\text { return on assets }\end{array}$} \\
\hline $\begin{array}{l}\text { Boțoc and } \\
\text { Anton } \\
(2017)\end{array}$ & $\begin{array}{l}937 \text { "gazelles" from } 13 \text { emerging } \\
\text { European economies and the period } \\
2006-2015\end{array}$ & \\
\hline $\begin{array}{l}\text { Yilmaz and } \\
\text { Acar (2019) }\end{array}$ & $\begin{array}{l}66 \text { non-financial Omani companies in } \\
\text { years 2013-2016 }\end{array}$ & $\begin{array}{l}\text { CCC has nonlinear significant effect on } \\
\text { gross profit margin and EBIT }\end{array}$ \\
\hline
\end{tabular}


Studies based on non-linear multivariable regression models (see: Table 1) have been conducted to a limited extent. They can be divided into two groups. The first one is a study using multivariable regression models with a lagged explanatory variable representing an indicator of WCM. The second group consists of studies based on models without any lags in the main explanatory variable.

The study of Singhania and Mehta (2017) is worth emphasizing as being a kind of summary of this research direction. The authors encompassed business units from 14 Far East countries. For the economies of Sri Lanka, India, Indonesia, Malaysia and Singapore, a square inverted dependence of CCC on asset profitability was detected. For companies from China, Pakistan, Bangladesh, Hong Kong and South Korea a positive square relationship was detected. In the case of Thailand, Taiwan and Vietnam, only a linear relationship was diagnosed.

Research on the relationship between WCM and profitability in the conditions of the Polish economy began relatively recently. First empirical studies were related to food industry. The research of Bieniasz and Gołaś (2011) showed a negative dependence between the profitability of companies and all elements of the operating cycle (including CCC). The authors also observed that the smaller the company, the stronger the relationship between profitability and working capital management. Slightly wider research was conducted in this sector by Zawadzka, Ardan and Szafraniec-Siluta (2011). Their research concerned agricultural enterprises in the years 2007-2009. Increasing ROA resulted in an increase in the quick liquidity ratio. A similar dependence was found by Paszko and Pawlak (2014) among fruit and vegetable processing companies. The most recent study demonstrated that in Polish dairy industry extending CCC exerts an adverse effect on ROA (Gołaś, 2020).

Among the studies from non-food sectors, the research of Wawryszuk-Misztal (2007) is worth mentioning. The author examined 82 companies belonging to the manufacturing sector in the years 1999-2006 listed on the WSE. But the most extensive research on the relationship between WCM indicators was conducted by Jaworski and Czerwonka (2018a, 2018 b). The first study of these authors, based on financial data of 251 companies listed on WSE in 1998-2015, proved a linear negative link between CCC and ROA of the analysed companies. In the second study, covering 345 companies listed on the WSE in 1998-2016, the researchers found a positive linear relationship between static liquidity ratios and ROA. This research confirmed the findings of previous study based on enterprises listed on the WSE (Bolek \& Wiliński, 2012).

Jaworski, Czerwonka and Mądra (2018) also studied food manufacturing enterprises. The research concerned 1046 companies in the years 2012-2015. No statistically significant relationship between profitability and financial liquidity was detected in the entire research sample. However, in terms of low liquidity values, a positive dependence was observed.

From the above review of empirical research it has not been possible to clearly indicate the dominant relation between WCM and profitability of Polish enterprises. Evidence indicating a linear negative relationship, especially for low values of working capital management indicators, prevails. This leads to the formulation of two research hypotheses

(H1): In the Polish economy conditions, as regards the listed companies, there has been negative relationship between WCM and profitability

(H2): The theoretical concept based on the flexible strategy of WCM explains best the decisions of enterprises listed on WSE. 
Nevertheless, there are reasons to believe that in certain conditions this dependence may have the opposite direction, or there may not be a significant dependence. The largest differences in diagnoses are noticeable for research conducted in various industries. It concerns studies in Polish economy and other countries as well. Therefore, third research hypothesis can be formulated:

(H3): The direction and shape of the relationship between WCM and profitability of enterprises listed on the WSE depend on an industry in which these enterprises operate.

\section{Research material and methodology}

An attempt to identify the strength and direction of the relationship between profitability and working capital management was based on variables defined in Table 2.

Table 2. Variables used in the study (source: own elaboration)

\begin{tabular}{|c|c|c|}
\hline Variable & Abbreviation & Definition \\
\hline \multicolumn{3}{|c|}{ Response variables } \\
\hline Return on assets & ROA & $\frac{\text { operating profit }}{\text { total assets }}$ \\
\hline \multicolumn{3}{|l|}{ Explanatory variables } \\
\hline Cash conversion cycle & $\mathrm{CCC}$ & $\mathrm{ITC}+\mathrm{ACP}-\mathrm{APP} *$ \\
\hline Financial liquidity & $\mathrm{CR}$ & $\frac{\text { current assets }}{\text { current liabilities }}$ \\
\hline Working capital & WC & $\frac{\text { current assets }- \text { current liabilities }}{\text { sales revenue }}$ \\
\hline \multicolumn{3}{|c|}{ Control variables } \\
\hline Size of the enterprise & SIZE & $\ln ($ total assets $)$ \\
\hline Financial leverage & LEV & $\frac{\text { total liabilities }}{\text { total assets }}$ \\
\hline $\begin{array}{l}\text { Gross domestic product } \\
\text { growth }\end{array}$ & GDP_GROW & percentage increase in GDP per year \\
\hline \multicolumn{3}{|c|}{ Explanations $^{*}$} \\
\hline Inventory turnover cycle & ITC & $\frac{\text { average amount of inventory }}{\text { sales revenue }} \times 365$ \\
\hline Average collection period & $\mathrm{ACP}$ & $\frac{\text { average amount of receivables }}{\text { sales revenue }} \times 365$ \\
\hline Accounts payable period & APP & $\frac{\text { average amount of current liabilities }}{\text { sales revenue }} \times 365$ \\
\hline
\end{tabular}


ROA was assumed as the response variable. This indicator applies to total assets, thus indirectly it is also shaped jointly by equity and debt. Since it has been most frequently used also in other studies, this has made this research outcomes widely comparable. As the main indicator of the WCM and the most frequently used in previous studies, CCC is the first, most important explanatory variable. In addition, it has been decided to include two other variables in the study: CR and WC. Their meaning in the WCM assessment has been described in the previous section of the paper.

Two first control variables (SIZE and LEV) were selected as the determinants of profitability most frequently mentioned in the literature (Deloof, 2003; Chang, 2018). Taking into account the long study period (18 years), a third control variable was included (GDP_GROW), adequate to the changing economic situation at that time.

The data for the calculation was taken from the Notoria database ${ }^{1}$. All companies listed on the WSE in years 1998-2016 were used in the study. The macro-sector Finance, companies with negative equity and companies with a limited scope of available data were excluded from the research sample. Due to the fact that certain data may have been incorrect and to avoid the impact of outliers the sample was restricted. One percent of observations were removed from the unlimited ends of LIQ and CCC distributions. In total, 326 companies and 2939 observations were included in the study. The distribution of observations for particular variables has been presented in Table 3.

Median of profitability is $6.1 \%$. Arithmetic mean value is almost the same (6.2\%). Also, for other variables there are no significant differences between median and mean. CCC is the most variable (coefficient of variation is 98\%) which translates into high extreme values (even +228 days). CR also reaches a high maximum value: 8.94 . This means that companies with excess liquidity are included in the sample.

Table 3. Descriptive statistics of the research sample (source: own elaboration)

\begin{tabular}{|l|c|c|c|c|c|c|c|}
\hline \multicolumn{1}{|c|}{ Variable } & Mean & Median & Std. dev. & Min & Max & Percentile 5\% & Percentile 95\% \\
\hline ROA & 0.062 & 0.061 & 0.100 & -1.134 & 0.693 & -0.078 & 0.199 \\
\hline CR & 1.683 & 1.406 & 1.025 & 0.071 & 8.942 & 0.689 & 3.855 \\
\hline CCC & 50.06 & 43.43 & 49.23 & -74.57 & 228.8 & -20.39 & 141.6 \\
\hline WC & 0.136 & 0.115 & 0.255 & -4.688 & 2.434 & -0.127 & 0.490 \\
\hline LEV & 0.482 & 0.477 & 0.179 & 0.056 & 0.988 & 0.190 & 0.788 \\
\hline SIZE & 12.62 & 12.40 & 1.709 & 8.059 & 20.28 & 10.20 & 15.77 \\
\hline GDP_GROW & 3.607 & 3.600 & 1.501 & 1.200 & 7.000 & 1.400 & 7.000 \\
\hline
\end{tabular}

In order to exclude multicollinearity between variables, Pearson correlation coefficients were calculated for each pair of variables (Table 4).

\footnotetext{
${ }^{1}$ Notoria database is conducted by Notoria Serwis SA (https://ir.notoria.pl/). It has been Polish official stock exchange information agency since 2009. Notoria is used and recommended by Warsaw Stock Exchange as a source of past financial information for market participants. Notoria Serwis SA has also been listed on WSE NewConnect market since 2009 .
} 
Table 4. Pearson correlation matrix for explanatory variables $($ critical value $=0.0362)$ (source: own elaboration)

\begin{tabular}{|c|c|c|c|c|c|c|}
\hline CR & CCC & WC & LEV & SIZE & GDP_GROW & \\
\hline 1.000 & 0.371 & 0.693 & -0.610 & -0.189 & 0.030 & CR \\
\hline & 1.000 & 0.406 & -0.309 & -0.091 & -0.001 & CCC \\
\hline & & 1.000 & -0.466 & -0.118 & 0.081 & WC \\
\hline & & & 1.000 & 0.055 & -0.019 & LEV \\
\hline & & & & 1.000 & -0.040 & SIZE \\
\hline & & & & & 1.000 & GDP_GROW \\
\hline
\end{tabular}

Values of coefficients do not indicate the existence of strong interdependencies. This means that there should not be a multicollinearity problem in panel models. Explanatory variables can be the basis for the estimation of parameters of panel models (Greene 2003).

All companies included in the research sample were assigned to one of 13 industries. Table 5 shows the distribution of CCC, WC and CR in each of them.

Table 5. CCC, WC and CR distribution according to industry (source: own elaboration)

\begin{tabular}{|c|c|c|c|c|c|c|c|c|c|c|}
\hline \multirow[b]{2}{*}{ Industry } & \multirow{2}{*}{$\begin{array}{l}\text { No. } \\
\text { obs. }\end{array}$} & \multicolumn{3}{|c|}{ CCC } & \multicolumn{3}{|c|}{ WC } & \multicolumn{3}{|c|}{ CR } \\
\hline & & Mean & Med. & $\begin{array}{l}\text { Std. } \\
\text { Dev. }\end{array}$ & Mean & Med. & $\begin{array}{l}\text { Std. } \\
\text { Dev. }\end{array}$ & Mean & Med. & $\begin{array}{l}\text { Std. } \\
\text { Dev. }\end{array}$ \\
\hline Agriculture & 68 & 86.49 & 83.60 & 51.11 & 0.232 & 0.345 & 0.603 & 2.565 & 2.212 & 1.444 \\
\hline $\begin{array}{l}\text { Food \& } \\
\text { beverage }\end{array}$ & 218 & 61.71 & 50.21 & 54.23 & 0.106 & 0.092 & 0.186 & 1.648 & 1.366 & 1.089 \\
\hline Automotive & 107 & 67.40 & 72.94 & 38.01 & 0.121 & 0.119 & 0.105 & 1.621 & 1.405 & 0.756 \\
\hline $\begin{array}{l}\text { Consumer } \\
\text { electronics }\end{array}$ & 22 & 37.45 & 33.30 & 35.97 & 0.089 & 0.073 & 0.082 & 1.283 & 1.290 & 0.250 \\
\hline Energy & 96 & 25.35 & 27.25 & 34.64 & 0.022 & 0.062 & 0.499 & 1.305 & 1.210 & 0.450 \\
\hline $\begin{array}{l}\text { Mining \& } \\
\text { metals }\end{array}$ & 504 & 67.14 & 63.21 & 51.38 & 0.161 & 0.151 & 0.179 & 1.661 & 1.495 & 0.821 \\
\hline Chemicals & 302 & 47.70 & 45.29 & 30.94 & 0.100 & 0.085 & 0.158 & 1.631 & 1.400 & 0.880 \\
\hline $\begin{array}{l}\text { Pharma \& } \\
\text { healthcare }\end{array}$ & 109 & 51.39 & 20.14 & 67.05 & 0.137 & 0.073 & 0.322 & 1.523 & 1.240 & 1.054 \\
\hline $\begin{array}{l}\text { Technology, } \\
\text { media \& } \\
\text { telecoms }\end{array}$ & 620 & 46.48 & 39.19 & 48.04 & 0.175 & 0.139 & 0.240 & 1.869 & 1.519 & 1.183 \\
\hline $\begin{array}{l}\text { Tourism \& } \\
\text { leisure }\end{array}$ & 83 & 10.29 & -1.34 & 40.54 & 0.075 & 0.036 & 0.566 & 1.643 & 1.186 & 1.459 \\
\hline $\begin{array}{l}\text { Consumer } \\
\text { goods \& } \\
\text { retail }\end{array}$ & 402 & 43.50 & 42.96 & 44.88 & 0.111 & 0.083 & 0.172 & 1.638 & 1.308 & 1.044 \\
\hline $\begin{array}{l}\text { Real estate \& } \\
\text { construction }\end{array}$ & 381 & 41.36 & 33.00 & 50.02 & 0.142 & 0.126 & 0.204 & 1.562 & 1.366 & 0.887 \\
\hline $\begin{array}{l}\text { Trans- } \\
\text { portation }\end{array}$ & 43 & 31.62 & 19.99 & 39.41 & 0.184 & 0.086 & 0.385 & 1.608 & 1.304 & 1.145 \\
\hline
\end{tabular}


This empirical study is organized in three stages. First, the relevance and impact of the explanatory variables on the response variables was identified and measured across the sample. For this purpose, the econometric panel models were applied. The research was based on two kinds of model. Non-linear models were used as primary ones. They include:

1. Regression model (Ordinary Least Squares Method/OLS):

$$
R O A_{i t}=\beta_{0}+\beta_{1} C C C_{i t}\left|C R_{i t}\right| W C_{i t}+\beta_{2} C C C_{i t}^{2}\left|C R_{i t}^{2}\right| W C_{i t}^{2}+\beta_{3} S I Z E_{i t}+\beta_{4} L E V_{i t}+\varepsilon_{i t} ;
$$

2. Model with fixed effects (FE)

$$
R O A_{i t}=\beta_{0}+\beta_{1} C C C_{i t}\left|C R_{i t}\right| W C_{i t}+\beta_{2} C C C_{i t}^{2}\left|C R_{i t}^{2}\right| W C_{i t}^{2}+\beta_{3} S I Z E_{i t}+\beta_{4} L E V_{i t}+\mu_{i t} ;
$$

3. Model with random effects (RE):

$$
R O A_{i t}=\beta_{0}+\beta_{1} C C C_{i t}\left|C R_{i t}\right| W C_{i t}+\beta_{2} C C C_{i t}^{2}\left|C R_{i t}^{2}\right| W C_{i t}^{2}+\beta_{3} S I Z E_{i t}+\beta_{4} L E V_{i t}+\varepsilon_{i t}+\mu_{i t} ;
$$

These models were used for checking the existence of non-linear dependence. As the second models, linear modifications of the abovementioned formulas were applied. In both cases the choice of the most relevant model between three mentioned sorts were based on the Breusch-Pagan and the Hausman tests. First test allows for determining the existence of individual effects. In order to identify fixed or random individual effects the Hausman test is applied. Information criteria (Schwarz Bayesian Information Criterion /SBC/, Akaike Information Criterion /AIC/, Hannan-Quinn Criterion /HQC/) were used as an additional aid. The testing procedure is from larger to smaller models. For the purpose of identifying the best-performing model type, irrelevant variables were eliminated. The lower the information criterion value, the better (Greene, 2003).

The second step of the study was aimed at detecting WCM's dependence on the industry. For this purpose, the one-way ANOVA variance analysis was applied (Lynch, 2013). As the CCC, WC and CR differentiation ranges, the industries assigned to the companies studied were used.

In the last step of the analysis, two of the industries were selected and used to build two research sub-samples. The selection criterion was the number of observations ensuring the reliability of the model and the identified differences in the diagnosed dependence of profitability on WCM measures. For each sub-sample the parameters of multiple regression models were estimated in accordance with the methodology adopted for the whole research sample.

\section{Research results}

Table 6 presents panel model estimation for full research sample. All models indicate that all three assumed WCM indicators are statistically significant. This means that WCM significantly exerts influence on profitability in enterprises studied. The control variables also turn out to significantly shape profitability in the company. The relationships between LEV, SIZE and ROA are negative and for GDP_GROW, the dependence proved to be positive. This means that the higher the indebtedness of enterprises, the lower their profitability. Increasing 
the size of enterprises causes decrease in their profitability. Profitability increases as economic situation improves.

Table 6. Results of model estimation (full sample) (source: own elaboration)

\begin{tabular}{|c|c|c|c|c|c|c|c|}
\hline Model & 1 & 2 & 3 & 4 & 5 & 6 & 7 \\
\hline $\begin{array}{l}\text { Panel } \\
\text { model } \\
\text { type }\end{array}$ & Fixed & Fixed & Fixed & Fixed & Fixed & Fixed & Fixed \\
\hline Const. & $\begin{array}{c}0.232^{\star * *} \\
(0.037)\end{array}$ & $\begin{array}{c}0.164^{\star * *} \\
(0.010)\end{array}$ & $\begin{array}{c}0.248^{* * *} \\
(0.038)\end{array}$ & $\begin{array}{c}0.242^{* * *} \\
(0.038)\end{array}$ & $\begin{array}{c}0.134^{* * *} \\
(0.040)\end{array}$ & $\begin{array}{c}0.225^{\star * *} \\
(0.039)\end{array}$ & $\begin{array}{l}0.132^{* * *} \\
(0.013)\end{array}$ \\
\hline CCC & $\begin{array}{c}0.0001 \\
(0.000099)\end{array}$ & $\begin{array}{c}-0.0004^{\star * *} \\
(0.0001)\end{array}$ & & & & & $\begin{array}{c}-0.0005^{* * *} \\
(0.0001)\end{array}$ \\
\hline $\mathrm{CCC}^{2}$ & $\begin{array}{c}-0.000003^{* * *} \\
(0.000001)\end{array}$ & & & & & & \\
\hline WC & & & $\begin{array}{l}0.018^{\star} \\
(0.009)\end{array}$ & $\begin{array}{c}0.027^{* * *} \\
(0.009)\end{array}$ & & & $\begin{array}{c}0.032^{\star * *} \\
(0.010\end{array}$ \\
\hline $\mathrm{WC}^{2}$ & & & $\begin{array}{l}-0.008^{* *} \\
(0.004)\end{array}$ & & & & \\
\hline CR & & & & & $\begin{array}{c}0.056^{* * *} \\
(0.007)\end{array}$ & $\begin{array}{c}0.008^{\star * *} \\
(0.003)\end{array}$ & $\begin{array}{l}0.006^{* *} \\
(0.003)\end{array}$ \\
\hline $\mathrm{CR}^{2}$ & & & & & $\begin{array}{c}-0.007^{\star * *} \\
(0.001)\end{array}$ & & \\
\hline LEV & $\begin{array}{c}-0.218^{\star * *} \\
(0.015)\end{array}$ & $\begin{array}{c}-0.235^{\star * *} \\
(0.015)\end{array}$ & $\begin{array}{c}-0.185^{\star * *} \\
(0.016)\end{array}$ & $\begin{array}{c}-0.177^{\star * *} \\
(0.016)\end{array}$ & $\begin{array}{c}-0.119^{* * *} \\
(0.018)\end{array}$ & $\begin{array}{c}-0.168^{\star * *} \\
(0.017)\end{array}$ & $\begin{array}{c}-0.191^{* * *} \\
(0.018)\end{array}$ \\
\hline SIZE & $\begin{array}{c}-0.006^{\star *} \\
(0.003)\end{array}$ & & $\begin{array}{c}-0.010^{\star * *} \\
(0.003)\end{array}$ & $\begin{array}{c}-0.010^{* * *} \\
(0.003)\end{array}$ & $\begin{array}{c}-0.009^{* * *} \\
(0.003)\end{array}$ & $\begin{array}{c}-0.010^{\star * *} \\
(0.003)\end{array}$ & \\
\hline $\begin{array}{l}\text { GDP_ } \\
\text { GROW }\end{array}$ & $\begin{array}{c}0.008^{\star * \star} \\
(0.001)\end{array}$ & $\begin{array}{c}0.009^{* * *} \\
(0.001)\end{array}$ & $\begin{array}{c}0.008^{\star * *} \\
(0.001)\end{array}$ & $\begin{array}{c}0.008^{\star * *} \\
(0.001)\end{array}$ & $\begin{array}{c}0.008^{* * *} \\
(0.001)\end{array}$ & $\begin{array}{c}0.008^{* * *} \\
(0.001)\end{array}$ & $\begin{array}{l}0.008^{* * *} \\
(0.001)\end{array}$ \\
\hline $\begin{array}{l}\text { No. of } \\
\text { obs. }\end{array}$ & 2939 & 2939 & 2939 & 2939 & 2939 & 2939 & 2939 \\
\hline $\begin{array}{l}\text { Joint } \\
\text { test on } \\
\text { named } \\
\text { regre- } \\
\text { ssors (F } \\
\text { test) }\end{array}$ & $\begin{array}{c}74.73 \\
p<0.001\end{array}$ & $\begin{array}{c}110.99 \\
p<0.001\end{array}$ & $\begin{array}{c}60.01 \\
p<0.001\end{array}$ & $\begin{array}{c}73.61 \\
p<0.001\end{array}$ & $\begin{array}{c}72.27 \\
p<0.001\end{array}$ & $\begin{array}{c}73.60 \\
p<0.001\end{array}$ & $\begin{array}{c}72.81 \\
p<0.001\end{array}$ \\
\hline $\begin{array}{l}\text { Breusch- } \\
\text { Pagan } \\
\text { test }\end{array}$ & $\begin{array}{c}797.11 \\
p<0.001\end{array}$ & $\begin{array}{c}812.23 \\
p<0.001\end{array}$ & $\begin{array}{c}771.12 \\
p<0.001\end{array}$ & $\begin{array}{c}777 \\
p<0.001\end{array}$ & $\begin{array}{c}758.04 \\
p<0.001\end{array}$ & $\begin{array}{c}715.92 \\
p<0.001\end{array}$ & $\begin{array}{c}781.75 \\
p<0.001\end{array}$ \\
\hline $\begin{array}{l}\text { Haus- } \\
\text { man test }\end{array}$ & $\begin{array}{c}36.12 \\
p<0.001\end{array}$ & $\begin{array}{c}33.80 \\
\mathrm{p}<0.001\end{array}$ & $\begin{array}{c}27.48 \\
\mathrm{p}<0.001\end{array}$ & $\begin{array}{c}27.16 \\
\mathrm{p}<0.001\end{array}$ & $\begin{array}{c}42.73 \\
\mathrm{p}<0.001\end{array}$ & $\begin{array}{c}47.83 \\
p<0.001\end{array}$ & $\begin{array}{c}54.72 \\
\mathrm{p}<0.001\end{array}$ \\
\hline SBC & -4361.482 & -4336.846 & -4288.083 & -4290.310 & -4349.341 & -4290.235 & -4351.999 \\
\hline AIC & -6324.832 & -6288.225 & -6251.433 & -6247.675 & -6312.692 & -6247.600 & -6315.349 \\
\hline HQC & -5617.882 & -5585.585 & -5544.483 & -5542.880 & -5605.742 & -5542.805 & -5608.399 \\
\hline
\end{tabular}

Note: ${ }^{*}$ dependence is significant at the level of $0.1{ }^{* *}$ dependence is significant at the level of $0.05 .{ }^{* * *}$ dependence is significant at the level of 0.01 (standard errors in parentheses). 
Testing models for CCC indicates that model 2 is more appropriate because it does not contain irrelevant variables that may interfere with the examined dependence. The relationship between ROA and CCC is linear and negative. This means that an increase in the cash conversion cycle causes a proportional decrease in profitability.

Non-linear model is the most relevant for WC and CR (the reduction in the number of variables has improved only 1 of the 3 information criteria; 2 of the 3 criteria are more favourable for the extended, non-linear WC model and 3 of 3 for the extended, non-linear CR model). On the basis of the conditional extremum method, the optimal WC value to maximize profitability is 1.125 . The same value for CR is 4 . The results obtained lead to very important conclusions: the relationship between liquidity and profitability is positive, the function is non-linear - concave. This means that when liquidity increases, profitability increases, but at a slower pace. It is also possible that when the maximum value is exceeded, the relation becomes negative. Similar relationship links profitability and amount of WC.

Model 7 is built for all assumed WCM indicators together. It confirms robustness of significance these indicators in shaping profitability of an enterprise.

In order to answer the research question P3, the effect of industry on individual WCM indicators was estimated using ANOVA analysis. The results of the calculations have been presented in Table 7.

Table 7. Results of ANOVA analysis (industry) (source: own elaboration)

\begin{tabular}{|c|l|c|c|c|c|c|}
\hline \multicolumn{2}{|c|}{} & Sum of squares & df & Mean squares & F & p-value \\
\hline \multirow{3}{*}{ CCC } & Industry & $562972(7.86 \%)$ & 12 & 46914.4 & 20.92 & $<0.001$ \\
\cline { 2 - 7 } & Error & 6596750 & 2942 & 2242.3 & & \\
\cline { 2 - 7 } & Total & 7159730 & 2954 & 2423.7 & & \\
\hline \multirow{4}{*}{ WC } & Industry & $4.47(2.33 \%)$ & 12 & 0.3729 & 5.85 & $<0.001$ \\
\cline { 2 - 7 } & Error & 187.619 & 2942 & 0.0638 & & \\
\cline { 2 - 7 } & Total & 192.093 & 2954 & 0.0650 & & \\
\hline \multirow{3}{*}{ CR } & Industry & $102.91(3.31 \%)$ & 12 & 8.5759 & 8.41 & $<0.001$ \\
\cline { 2 - 7 } & Error & 3001.28 & 2942 & 1.0206 & & \\
\cline { 2 - 7 } & Total & 3104.19 & 2954 & 1.0508 & & \\
\hline
\end{tabular}

Note: The ratio of the sum of squares explained by industry to the total sum in parenthesis.

All WCM indicators turn out to be diversified by enterprise industry in statistically significant way. Industry change explains $8 \%$ of CCC variability, $3 \%$ of CR variability and $2 \%$ of WC variability. This means that industry is an important determinant of WCM. Taking into account number of observations (credibility of models), two industries were analysed in detail. However, to ensure that the largest sample size is not the only determinant, the first and last sectors, of those with a sample size above 300, were used. Sub-samples of data for "Chemicals" and "Technology, media \& telecoms" were the basis for the estimation of parameters of panel models analogous to the models calculated for the whole sample. Table 8 presents research outcomes for "Chemicals", Table 9 for "Technology, media \& telecoms". 
Table 8. Results of model estimation ("Chemicals" industry) (source: own elaboration)

\begin{tabular}{|c|c|c|c|c|c|c|c|}
\hline Model & 8 & 9 & 10 & 11 & 12 & 13 & 14 \\
\hline $\begin{array}{l}\text { Panel } \\
\text { model } \\
\text { type }\end{array}$ & Random & Random & Random & Random & Random & Random & Random \\
\hline Const. & $\begin{array}{l}0.116^{\star \star} \\
(0.051)\end{array}$ & $\begin{array}{c}0.144^{* * *} \\
(0.023)\end{array}$ & $\begin{array}{l}0.116^{\star *} \\
(0.049)\end{array}$ & $\begin{array}{c}0.117^{* * *} \\
(0.023)\end{array}$ & $\begin{array}{c}0.078 \\
(0.057)\end{array}$ & $\begin{array}{c}0.108^{* * *} \\
(0.028)\end{array}$ & $\begin{array}{c}0.072 \\
(0.053)\end{array}$ \\
\hline CCC & $\begin{array}{l}-0.000221 \\
(0.000351)\end{array}$ & $\begin{array}{c}-0.0003^{\star} \\
(0.0002)\end{array}$ & & & & & $\begin{array}{c}-0.0004^{* *} \\
(0.0002)\end{array}$ \\
\hline $\mathrm{CCC}^{2}$ & $\begin{array}{c}-0.000001 \\
(0.000003)\end{array}$ & & & & & & \\
\hline WC & & & $\begin{array}{c}0.062 \\
(0.039)\end{array}$ & $\begin{array}{c}0.025 \\
(0.034)\end{array}$ & & & $\begin{array}{c}0.037 \\
(0.044)\end{array}$ \\
\hline $\mathrm{WC}^{2}$ & & & $\begin{array}{c}-0.134^{\star *} \\
(0.062)\end{array}$ & & & & \\
\hline $\mathrm{CR}$ & & & & & $\begin{array}{c}0.031 \\
(0.019)\end{array}$ & $\begin{array}{c}0.006 \\
(0.006)\end{array}$ & $\begin{array}{c}0.004 \\
(0.008)\end{array}$ \\
\hline $\mathrm{CR}^{2}$ & & & & & $\begin{array}{l}-0.004 \\
(0.003)\end{array}$ & & \\
\hline LEV & $\begin{array}{c}-0.197^{\star * *} \\
(0.035)\end{array}$ & $\begin{array}{c}-0.193^{\star * *} \\
(0.034)\end{array}$ & $\begin{array}{c}-0.154^{\star * *} \\
(0.039)\end{array}$ & $\begin{array}{c}-0.167^{* * *} \\
(0.039)\end{array}$ & $\begin{array}{c}-0.144^{* * *} \\
(0.042)\end{array}$ & $\begin{array}{c}-0.163^{* * *} \\
(0.039)\end{array}$ & $\begin{array}{c}-0.171^{* * *} \\
(0.041)\end{array}$ \\
\hline SIZE & $\begin{array}{c}0.002 \\
(0.004)\end{array}$ & & $\begin{array}{l}0.0002 \\
(0.004)\end{array}$ & & $\begin{array}{c}-0.0004 \\
(0.004)\end{array}$ & & $\begin{array}{c}0.004 \\
(0.004)\end{array}$ \\
\hline $\begin{array}{l}\text { GDP_ } \\
\text { GROW }\end{array}$ & $\begin{array}{c}0.007^{\star * *} \\
(0.002)\end{array}$ & $\begin{array}{c}0.007^{\star * *} \\
(0.002)\end{array}$ & $\begin{array}{c}0.006^{* * *} \\
(0.002)\end{array}$ & $\begin{array}{c}0.007^{* * *} \\
(0.002)\end{array}$ & $\begin{array}{c}0.007^{* * *} \\
(0.002)\end{array}$ & $\begin{array}{c}0.007^{* * *} \\
(0.002)\end{array}$ & $\begin{array}{c}0.007^{* * *} \\
(0.002)\end{array}$ \\
\hline $\begin{array}{l}\text { No. of } \\
\text { obs. }\end{array}$ & 300 & 300 & 300 & 300 & 300 & 300 & 300 \\
\hline $\begin{array}{l}\text { Joint } \\
\text { test on } \\
\text { named } \\
\text { regre- } \\
\text { ssors } \\
\text { (F test) }\end{array}$ & $\begin{array}{c}44.22 \\
p<0.001\end{array}$ & $\begin{array}{c}43.55 \\
p<0.001\end{array}$ & $\begin{array}{c}44.96 \\
\mathrm{p}<0.001\end{array}$ & $\begin{array}{c}41.04 \\
\mathrm{p}<0.001\end{array}$ & $\begin{array}{c}43.82 \\
p<0.001\end{array}$ & $\begin{array}{c}41.38 \\
\mathrm{p}<0.001\end{array}$ & $\begin{array}{c}48.23 \\
p<0.001\end{array}$ \\
\hline $\begin{array}{l}\text { Breusch- } \\
\text { Pagan } \\
\text { test }\end{array}$ & $\begin{array}{c}183.79 \\
p<0.001\end{array}$ & $\begin{array}{c}187.81 \\
p<0.001\end{array}$ & $\begin{array}{c}126.018 \\
\mathrm{p}<0.001\end{array}$ & $\begin{array}{c}171.02 \\
\mathrm{p}<0.001\end{array}$ & $\begin{array}{c}174.89 \\
\mathrm{p}<0.001\end{array}$ & $\begin{array}{c}179.71 \\
\mathrm{p}<0.001\end{array}$ & $\begin{array}{c}171.98 \\
p<0.001\end{array}$ \\
\hline $\begin{array}{l}\text { Haus- } \\
\text { man test }\end{array}$ & $\begin{array}{c}4.57 \\
\mathrm{p}=0.47\end{array}$ & $\begin{array}{c}4.16 \\
\mathrm{p}=0.244\end{array}$ & $\begin{array}{c}10.62 \\
\mathrm{p}=0.06\end{array}$ & $\begin{array}{c}6.01 \\
\mathrm{p}=0.11\end{array}$ & $\begin{array}{c}5.85 \\
\mathrm{p}=0.32\end{array}$ & $\begin{array}{c}5.46 \\
\mathrm{p}=0.14\end{array}$ & $\begin{array}{c}5.82 \\
\mathrm{p}=0.44\end{array}$ \\
\hline SBC & -692.225 & -702.234 & -697.466 & -695.487 & -685.51 & -697.15 & -684.75 \\
\hline AIC & -714.448 & -717.049 & -719.689 & -710.302 & -707.737 & -711.970 & -710.68 \\
\hline HQC & -705.554 & -711.120 & -710.796 & -704.373 & -698.844 & -706.041 & -700.31 \\
\hline
\end{tabular}

Note: ${ }^{*}$ dependence is significant at the level of $0.1 .{ }^{* *}$ dependence is significant at the level of $0.05 .{ }^{* * *}$ dependence is significant at the level of 0.01 . (standard errors in parentheses). 
In sub-sample for "Chemicals" industry the relationship between ROA and CCC is best described by model 9. This means that this dependence is linear and negative, and it does not differ from the relation detected for the whole research sample. In the case of both other WCM indicators (WC and CR) the significance of the relationship between them and ROA is not specified. The same fact concerns the control variable SIZE. The relationship between LEV and GDP_GROW control variables is significant, and its direction is consistent with that found for the whole research sample. Robustness check (model 14) confirms that ROA depends only on CCC.

Table 9. Results of model estimation (“Technology, media \& telecoms” industry) (source: own elaboration)

\begin{tabular}{|c|c|c|c|c|c|c|c|}
\hline Model & 15 & 16 & 17 & 18 & 19 & 20 & 21 \\
\hline $\begin{array}{l}\text { Panel } \\
\text { model } \\
\text { type }\end{array}$ & Fixed & Fixed & Random & Fixed & Fixed & Fixed & Fixed \\
\hline Const. & $\begin{array}{c}0.428^{\star * *} \\
(0.088)\end{array}$ & $\begin{array}{c}0.402^{\star * \star} \\
(0.087)\end{array}$ & $\begin{array}{c}0.401^{* * *} \\
(0.091)\end{array}$ & $\begin{array}{c}0.401^{* * *} \\
(0.092)\end{array}$ & $\begin{array}{l}0.230^{* *} \\
(0.103)\end{array}$ & $\begin{array}{c}0.339^{* * *} \\
(0.094)\end{array}$ & $\begin{array}{c}0.017 \\
(0.105) \\
\end{array}$ \\
\hline CCC & $\begin{array}{l}-0.00002 \\
(0.00026) \\
\end{array}$ & $\begin{array}{c}-0.0004^{\star * *} \\
(0.0001)\end{array}$ & & & & & $\begin{array}{c}-0.001^{* * *} \\
(0.0002)\end{array}$ \\
\hline $\mathrm{CCC}^{2}$ & $\begin{array}{c}-0.000003^{\star *} \\
(0.000002)\end{array}$ & & & & & & \\
\hline WC & & & $\begin{array}{c}0.047 \\
(0.031)\end{array}$ & $\begin{array}{l}-0.001 \\
(0.027)\end{array}$ & & & $\begin{array}{c}0.004 \\
(0.034)\end{array}$ \\
\hline $\mathrm{WC}^{2}$ & & & $\begin{array}{c}-0.083^{* * *} \\
(0.029)\end{array}$ & & & & \\
\hline CR & & & & & $\begin{array}{c}0.048^{* * *} \\
(0.016)\end{array}$ & $\begin{array}{l}0.011^{*} \\
(0.006)\end{array}$ & $\begin{array}{l}0.016^{* *} \\
(0.007)\end{array}$ \\
\hline $\mathrm{CR}^{2}$ & & & & & $\begin{array}{c}-0.005^{* *} \\
(0.002)\end{array}$ & & \\
\hline LEV & $\begin{array}{c}-0.297^{\star * *} \\
(0.041)\end{array}$ & $\begin{array}{c}-0.312^{\star * *} \\
(0.041)\end{array}$ & $\begin{array}{c}-0.253^{* * *} \\
(0.045)\end{array}$ & $\begin{array}{c}-0.265^{\star * *} \\
(0.045)\end{array}$ & $\begin{array}{c}-0.160^{* * *} \\
(0.051)\end{array}$ & $\begin{array}{c}-0.214^{* * *} \\
(0.047)\end{array}$ & $\begin{array}{l}-0.244^{* * *} \\
(0.049)\end{array}$ \\
\hline SIZE & $\begin{array}{c}-0.020^{* * *} \\
(0.007)\end{array}$ & $\begin{array}{c}-0.017^{* *} \\
(0.007)\end{array}$ & $\begin{array}{c}-0.020^{* * *} \\
(0.007)\end{array}$ & $\begin{array}{c}-0.020^{* * *} \\
(0.007)\end{array}$ & $\begin{array}{l}-0.015^{\star *} \\
(0.007)\end{array}$ & $\begin{array}{c}-0.018^{* * *} \\
(0.007)\end{array}$ & $\begin{array}{c}0.010 \\
(0.008)\end{array}$ \\
\hline $\begin{array}{l}\text { GDP_ } \\
\text { GROW }\end{array}$ & $\begin{array}{c}0.007^{* * *} \\
(0.003)\end{array}$ & $\begin{array}{c}0.008^{\star * *} \\
(0.003)\end{array}$ & $\begin{array}{l}0.006^{* *} \\
(0.003)\end{array}$ & $\begin{array}{c}0.007^{* * *} \\
(0.003)\end{array}$ & $\begin{array}{l}0.006^{* *} \\
(0.003)\end{array}$ & $\begin{array}{l}0.007^{\star *} \\
(0.003)\end{array}$ & $\begin{array}{c}0.008^{* * *} \\
(0.003)\end{array}$ \\
\hline No. of obs. & 616 & 616 & 616 & 616 & 616 & 616 & 616 \\
\hline $\begin{array}{l}\text { Joint test } \\
\text { on named } \\
\text { regressors } \\
\text { (F test) }\end{array}$ & $\begin{array}{c}16.08 \\
p<0.001\end{array}$ & $\begin{array}{c}5.56 \\
p<0.001\end{array}$ & $\begin{array}{c}75.31 \\
p<0.001\end{array}$ & $\begin{array}{c}16.42 \\
p<0.001\end{array}$ & $\begin{array}{c}15.27 \\
p<0.001\end{array}$ & $\begin{array}{c}17.34 \\
p<0.001\end{array}$ & $\begin{array}{c}13.05 \\
p<0.001\end{array}$ \\
\hline $\begin{array}{l}\text { Breusch- } \\
\text { Pagan test }\end{array}$ & $\begin{array}{c}161.58 \\
p<0.001\end{array}$ & $\begin{array}{c}166.85 \\
p<0.001\end{array}$ & $\begin{array}{c}156.96 \\
p<0.001\end{array}$ & $\begin{array}{c}166.8 \\
p<0.001\end{array}$ & $\begin{array}{c}170.20 \\
p<0.001\end{array}$ & $\begin{array}{c}163.95 \\
p<0.001\end{array}$ & $\begin{array}{c}157.74 \\
\mathrm{p}<0.001\end{array}$ \\
\hline $\begin{array}{l}\text { Hausman } \\
\text { test }\end{array}$ & $\begin{array}{c}17.70 \\
p=0.003\end{array}$ & $\begin{array}{c}16.74 \\
p=0.002\end{array}$ & $\begin{array}{c}10.91 \\
p=0.053\end{array}$ & $\begin{array}{c}12.34 \\
p=0.015\end{array}$ & $\begin{array}{c}13.25 \\
p=0.02\end{array}$ & $\begin{array}{c}15.05 \\
\mathrm{p}=0.005\end{array}$ & $\begin{array}{c}21.02 \\
p=0.002\end{array}$ \\
\hline SBC & -777.082 & -779.117 & -771.241 & -768.663 & -773.065 & -772.366 & -768.73 \\
\hline AIC & -1099.979 & -1097.590 & -1094.138 & -1087.137 & -1095.962 & -1090.840 & -1096.06 \\
\hline HQC & -974.430 & -973.761 & -968.589 & -963.308 & -970.413 & -967.011 & -968.79 \\
\hline
\end{tabular}

Note: ${ }^{*}$ dependence is significant at the level of $0.1{ }^{* *}$ dependence is significant at the level of $0.05 .{ }^{* *}$ dependence is significant at the level of 0.01 (standard errors in parentheses). 
The linear model also has a stronger basis for determining the relationship between CCC and ROA for the "Technology, media \& telecoms" industry. In this case, however, it is not so clear as for "Chemicals" and for the sample as a whole. The relationship between CR and ROA is best described by model 19 . The disappearance of the square variable deteriorated the information criteria of the model and worsened the statistical significance of the main explanatory variable. There are premises to consider that similar dependence link WC and ROA, but taking into consideration ambiguous results of both models (17 and 18) this has not been resolved. All models confirm the same direction and significance of the relationship between control variables and ROA as for the whole research sample. Robustness check (model 21) confirms that ROA is shaped by CCC and CR. The relationship between ROA and WC has turned out to be statistically insignificant.

\section{Discussion}

The detected relationship between CCC and the profitability of enterprises for the whole research sample is consistent with the results of previous studies in Poland (WawryszukMisztal, 2007; Jaworski \& Czerwonka, 2018a). It has also been determined for the two subsamples (industries) studied. The direction of this relationship is also consistent with the dominant dependency in many economies established by Singh et al. (2017). This means that the results of the study are a strong confirmation of the negative linear relationship between the most important WCM efficiency indicator (CCC) and the company's profitability for companies listed on the WSE. These outcomes complement the research of other authors and they are in line with the current state of knowledge.

Taking the above fact into account, there is a premise to support the H1 research hypothesis: In Polish economy conditions, for listed companies, there is negative relationship between WCM and profitability. However, the results obtained in terms of dependence of the other two WCM indicators (WC and CR) on profitability contradict this thesis. In both cases there is evidence of the existence of a non-linear relationship (the whole research sample) or its absence (industries). The ambiguity of the results obtained, as regards the relationships between profitability and all examined WCM indicators, does not allow for supporting the hypothesis (H2) clearly, as well (The theoretical concept based on the flexible strategy of WCM best explains decision of enterprises listed on WSE). However, the outcomes of this research clearly do not negate this thesis.

On the one hand, the observed dependence significantly changes the attitude to the results obtained so far (Bolek \& Wiliński, 2012; Jaworski \& Czerwonka, 2018b), on the other, it justifies some of them (Jaworski et al., 2018). However, in both cases, this research does not nullify them.

The results of the ANOVA analysis clearly support the third research hypothesis: $(\mathrm{H} 3)$ : The direction and shape of the relationship between WCM and profitability of enterprises listed on the WSE depend on industry in which these enterprises operate. It has been shown that belonging to a particular industry differentiates all WCM indicators. However, the scope of their variability determined by the industry is different: $8 \%$ for CCC, $2 \%$ for WC and $3 \%$ for CR. Studies of the shape, strength and direction of the relationship between WCM and 
ROA for two sample industries show that the industry's impact on WCM also translates into the relationship between WCM and the company's profitability. This strengthens the support of the $\mathrm{H} 3$ hypothesis.

\section{Conclusions}

In the case of the relationship between CR and ROA, the results of the study indicate a possible relationship similar to the Gentry's curve. The estimated level of CR at which ROA maximizes its value is 4 . This calculation is based on a partial derivative, which means that it must be combined with the assumption "ceteris paribus". Decisions of real entities are also influenced by other factors, including environmental or behavioural ones. Hence, the results of the study indicate that this dependence is non-linear, there is an optimum, although not always in the range that most companies reach, also for other reasons. However, it can be seen in Table 3, this value is in the range of CR obtained by the enterprises studied.

A similar relationship as between CR and ROA was found for WC. However, in this case, the maximum WC values in the research samples (see Tables 3 and 5) slightly exceeded the estimated value maximizing ROA (1.1). This means that the occurrence of a relationship consistent with the Gentry's curve is less likely here. But, the relationship is undoubtedly nonlinear and positive for the most part of WC value. This is an interesting observation taking into account the negative relationship between ROA and CCC. The main sources of financing for CCC are equity and long-term liabilities corresponding to $\mathrm{WC}$, and alternatively a short-term bank loan. Therefore, an increasing WC with a decreasing CCC may mean that as the profitability increases, companies pay off their short-term bank loans faster than the increase in WC. This hypothesis requires further study.

The results of the research also have some implications for business practice. Firstly, managers of companies with growing profitability should not lose sight of the shortening CCC when paying off short-term loans. The shorter the CCC, the higher the financial risk. And secondly, in some industries ("Agriculture", "Technology, media \& telecoms", "Food and beverage"), decreasing profitability, with CR values growing, may mean problems with the efficient use of current assets. The results are based on data analysis of a relatively long period (18 years out of the 25 years of the WSE's existence until 2016). This indicates that the relationships found are quite persistent and these results should also be relevant for many years to come.

The results of this study indicate an interesting future direction of research: dependence of WCM on profitability in particular industries. However, this requires the extension of research samples to increase the quality and reliability of the results obtained.

The main limitations of this study include: 1) a research sample based only on the data of enterprises listed on the WSE prevents simple approximation of results to all Polish enterprises, 2) one measure of profitability (ROA) applied may not fully describe the impact of WCM on profitability 3 ) there are low reliability models for specific industries due to narrow research samples. 


\section{Author contributions}

LCZ and JJ conceived the study and were responsible for the design of the research. JJ was responsible for the literature review. LCZ was responsible for data collection and the development of the data analysis. LCZ and JJ were responsible for data interpretation.

\section{Disclosure statement}

The authors declare no conflict of interest.

\section{References}

Afrifa, G. A. (2016). Net working capital, cash flow and performance of UK SMEs. Review of Accounting and Finance, 15(1), 21-44. https://doi.org/10.1108/RAF-02-2015-0031

Akgün, A. I., \& Karataş, A. M. (2021). Investigating the relationship between working capital management and business performance: Evidence from the 2008 financial crisis of EU-28. International Journal of Managerial Finance, 17(4), 545-567. https://doi.org/10.1108/IJMF-08-2019-0294

Alarussi, A. S., \& Alhaderi, S. M. (2018). Factors affecting profitability in Malaysia. Journal of Economic Studies, 45(3), 442-458. https://doi.org/10.1108/JES-05-2017-0124

Baños-Caballero, S., García-Teruel, P. J., \& Martínez-Solano, P. (2012). How does working capital management affect the profitability of Spanish SMEs? Small Business Economics, 39(2), 517-529. https://doi.org/10.1007/s11187-011-9317-8

Baser, F., Gokten, S., Kucukkocaoglu, G., \& Ture, H. (2016). Liquidity-profitability tradeoff existance in Turkey: An empirical investigation under structural equation modeling. Copernican Journal of Finance \& Accounting, 5(2), 27-43. https://doi.org/10.12775/CJFA.2016.013

Bieniasz, A., \& Gołaś, Z. (2011). The influence of working capital management on the food industry enterprises profitability. Contemporary Economics, 5(4), 68-81. https://doi.org/10.5709/ce.1897-9254.29

Bolek, M., \& Wiliński, W. (2012). The influence of liquidity on profitability of Polish construction sector companies. E-Finanse: Financial Internet Quarterly, 8(1), 38-52. https://www.econstor.eu/bitstream/10419/66742/1/721357075.pdf

Boțoc, C., \& Anton, S. G. (2017). Is profitability driven by working capital management? Evidence for high-growth firms from emerging Europe. Journal of Business Economics and Management, 18(6), 1135-1155. https://doi.org/10.3846/16111699.2017.1402362

Brealey, R. A., Myers, S. C., \& Allen, F. (2016). Principles of corporate finance (12 ${ }^{\text {th }}$ ed.). McGraw-Hill Education. https://www.amazon.com/Principles-Corporate-Finance-Connect-Richard/dp/1259692175

Capkun, V., Hameri, A. P., \& Weiss, L. A. (2005). On the relationship between inventory and financial performance in manufacturing companies. International Journal of Operations \& Production Management, 29(8), 789-806. https://doi.org/10.1108/01443570910977698

Chang, C. C. (2018). Cash conversion cycle and corporate performance: Global evidence. International Review of Economics and Finance, 56, 568-581. https://doi.org/10.1016/j.iref.2017.12.014

Charitou, M., Lois, P., \& Santoso, H. B. (2012). The relationship between working capital management and firm's profitability: A empirical investigation for an emerging Asian country. International Business and Economics Research Journal, 11(8), 839-849. https://doi.org/10.19030/iber.v11i8.7162

Deloof, M. (2003). Does working capital management affect profitability of Belgian firms? Journal of Business Finance and Accounting, 30(3/4), 573-587. https://doi.org/10.1111/1468-5957.00008 
Diakomihalis, M. N. (2012). The accuracy of Altman's models in predicting hotel bankruptcy. International Journal of Accounting and Financial Reporting, 2(2), 96-113. https://doi.org/10.5296/ijafr.v2i2.2367

Ding, S., Guariglia, A., \& Knight, J. (2013). Investment and financing constraints in China: Does working capital management make a difference? Journal of Banking and Finance, 37(5), 1490-1507. https://doi.org/10.1016/j.jbankfin.2012.03.025

Ebben, J. J., \& Johnson, A. C. (2011). Cash conversion cycle management in small firms: Relationships with liquidity, invested capital, and firm performance. Journal of Small Business and Entrepreneurship, 24(3), 381-396. https://doi.org/10.1080/08276331.2011.10593545

Gallinger, G. W. (1997). The current and quick ratios: Do they stand up to scrutiny. Business Credit, 99(5), 24-25.

Gentry, J. (1976). Management perceptions of the working capital process (Faculty Working Papers, 352). College of Commerce and Business Administration, University of Illinois at Urbana-Champaign, Illinois. https://core.ac.uk/download/pdf/4835142.pdf

Gill, A., Biger, N., \& Mathur, N. (2010). The relationship between working capital management and profitability: Evidence from the United States. Business and Economics Journal, 2010(BEJ-10), 1-10. https://www.researchgate.net/publication/284875433_The_Relationship_Between_Working_Capital_Management_And_Profitability_Evidence_From_The_United_States

Gitman, L. J. (1974). Estimating corporate liquidity requirements: A simplified approach. Financial Review, 9(1), 79-88. https://doi.org/10.1111/j.1540-6288.1974.tb01453.x

Gołaś, Z. (2020). Impact of working capital management on business profitability: Evidence from the Polish dairy industry. Agricultural Economics / Zemedelska Ekonomika, 66(6), 278-285. https://doi.org/10.17221/335/2019-AGRICECON

Greene, W. H. (2003). Econometric analysis. Prentice Hall.

Jaworski, J., \& Czerwonka, L. (2018a). Cykl operacyjny i jego elementy składowe a rentowność spółek notowanych na GPW w Warszawie. Prace Naukowe Uniwersytetu Ekonomicznego We Wrocławiu, 533, 110-118. https://doi.org/10.15611/pn.2018.533.11

Jaworski, J., \& Czerwonka, L. (2018b). Relationship between profitability and liquidity of enterprises listed on Warsaw stock exchange. In H. Ribeira, D. Naletina, \& A. L. da Silva (Eds.), Economic and Social Development. $35^{\text {th }}$ International Scientific Conference on Economic and Social Development - "Sustainability from an Economic and Social Perspective" Book of Proceedings (pp. 326-334). Varazdin Development and Entrepreneurship Agency. https://www.esd-conference.com/upload/ book_of_proceedings/Book_of_Proceedings_esdLisbon2018_Online.pdf

Jaworski, J., Czerwonka, L., \& Mądra-Sawicka, M. (2018). Zależność między rentownością a płynnością finansową w sektorze przetwórstwa spożywczego w Polsce. Roczniki Naukowe Stowarzyszenia Ekonomistów Rolnictwa i Agrobiznesu, 20(1), 58-63. https://doi.org/10.5604/01.3001.0011.7229

Kayani, U. N., De Silva, T.-A., \& Gan, Ch. (2020). Working capital management and firm performance relationship: An empirical investigation of Australasian firms. Review of Pacific Basin Financial Markets and Policies, 23(3), 20500265. https://doi.org/10.1142/S0219091520500265

Khan, N., Bilal, M., Malik, I. R., Kashif, A. R., \& Sajid, A. R. (2020). Relationship of working capital to corporate performance and stock price: Evidence from the manufacturing sector of Pakistan. International Transaction Journak of Engineering Management \& Applied Sciences \& Technologies, 11(13), 1-11. https://doi.nrct.go.th//ListDoi/listDetail?Resolve_DOI=10.14456/itjemast.2020.267

Kieschnick, R. L., Laplante, M., \& Moussawi, R. (2011). Working capital management and shareholder wealth. Review of Finance, 17(5), 1827-1852. https://doi.org/10.1093/rof/rfs043

Le, B. (2019). Working capital management and firm's valuation, profitability and risk: Evidence from a developing market. International Journal of Managerial Finance, 15(2), 191-204.

https://doi.org/10.1108/IJMF-01-2018-0012 
Li, C. G., Dong, H. M., Chen, S., \& Yang, Y. (2014). Working capital management, corporate performance, and strategic choices of the wholesale and retail industry in China. Scientific World Journal, 2014, 1-16. https://doi.org/10.1155/2014/953945

Lynch, S. M. (2013). Comparing means across multiple groups: Analysis of variance (ANOVA). In Using statistics in social research (pp. 117-126). Springer. https://doi.org/10.1007/978-1-4614-8573-5_8

Mun, S. G., \& Jang, S. C. S. (2015). Working capital, cash holding, and profitability of restaurant firms. International Journal of Hospitality Management, 48, 1-11. https://doi.org/10.1016/j.ijhm.2015.04.003

Notoria Serwis. (n.d.). Dane finansowe dla inwestorów. https://ir.notoria.pl/

Opler, T., Pinkowitz, L., Stulz, R., \& Wiliamson, R. (1999). The determinants and implications of corporate cash holdings. Journal of Financial Economics, 52(1), 3-46. https://doi.org/10.1016/S0304-405X(99)00003-3

Paszko, D., \& Pawlak, J. (2014). Rentowność kapitału własnego a poziom płynności i warzyw. Roczniki Naukowe Ekonomii Rolnictwa i Rozwoju Obszarów Wiejskich, 101(3), 162-170. http://sj.wne.sggw.pl/article-RNR_2014_n3_s162/

Perković, G. (2012). The impact of working capital management on profitability of manufacturing firms in Bosnia and Herzegovina. Sarajevo Business and Economics Review, 32, 117-138.

Raheman, A., Afza, T., Qayyum, A., \& Bodla, M. (2010). Working capital management and corporate performance of manufacturing sector in Pakistan. International Research Journal of Finance and Economics, 47(1), 156-169. https://www.researchgate.net/publication/50341524_Working_Capital_Management_and_Corporate_Performance_of_Manufacturing_Sector_in_Pakistan

Ren, T., Liu, N., Yang, H., Xiao, Y., \& Hu, Y. (2019). Working capital management and firm performance in China. Asian Review of Accounting, 27(4), 546-562. https://doi.org/10.1108/ARA-04-2018-0099

Smith, K. (1980). Profitability versus liquidity tradeoffs in working capital management. In K. Smith (Ed.), Readings on the management of working capital (pp. 549-562). West Publishing Company.

Singh, H. P., Kumar, S., \& Colombage, S. (2017). Working capital management and firm profitability: A meta-analysis. Qualitative Research in Financial Markets, 9(1), 34-47. https://doi.org/10.1108/QRFM-06-2016-0018

Singhania, M., \& Mehta, P. (2017). Working capital management and firms' profitability: Evidence from emerging Asian countries. South Asian Journal of Business Studies, 6(1), 80-97. https://doi.org/10.1108/SAJBS-09-2015-0060

Thapa, P. (2013). How does profitability get affected by working capital management in food and beverages industry? Munich Personal RePEc Archive, IV(50926), 1-15.

https://mpra.ub.uni-muenchen.de/50926/1/MPRA_paper_50865.pdf

Wawryszuk-Misztal, A. (2007). Zależność między zarządzaniem kapitałem obrotowym netto a rentownością na przykładzie spółek notowanych na Giełdzie Papierów Wartościowych w Warszawie. Annales Universitatis Mariae Curie-Skłodowska. Sectio H: Oeconomica, 41(20), 277-287. http://yadda.icm.edu.pl/yadda/element/bwmeta1.element.ekon-element-000171331433

Yilmaz, I., \& Acar, G. (2019). The effect of cash conversion cycle on profitability Omani companies. International Journal of Economics Management and Accounting, 27(2), 269-290.

https://journals.iium.edu.my/enmjournal/index.php/enmj/article/view/654

Zawadzka, D., Ardan, R., \& Szafraniec-Siluta, E. (2011). Płynność finansowa a rentowność przedsiębiorstw rolnych w Polsce - ujęcie modelowe. Zeszyty Naukowe SGGW. Ekonomika i Organizacja Gospodarki Żywnościowej, 88, 195-207. http://yadda.icm.edu.pl/yadda/element/bwmeta1.element. ekon-element-000171375999 